\title{
THE "DEGRADED" LANDSCAPE OF A POST-SOVIET MILITARY BASE IN POLAND: OUTSIDE VS. INSIDE VIEW
}

\author{
Dominika Czarnecka \\ Institute of Archaeology and Ethnology \\ Polish Academy of Sciences, Poland \\ e-mail:d.czarnecka@hotmail.com
}

\begin{abstract}
This article focuses on the context and lasting consequences of the withdrawal of the Russian Federation military forces from the town of Borne Sulinowo in Poland in the 1990s. Combining an analysis of local and all-Polish media with interviews and observations conducted in Borne Sulinowo, the article distinguishes between insiders' and outsiders' perspectives on this former military base in order to demonstrate how degradation was as much a feature of the local natural landscape and built environment as it was a cultural and political construct serving the interests of the post-socialist state. Rather than inventorying environmental and economic damages, this article aims to present the multidimensionality and relativity of the phenomenon of degradation in the context of the landscape of a former Soviet base. By reconstructing facts, opinions, and myths related to the "degraded" landscape of a former military base, different perspectives and ways of seeing become apparent.
\end{abstract}

Keywords: Borne Sulinowo, Cold War, degradation, landscape, legacy, Poland, post-Soviet military base, ruins, ways of seeing

The end of the Cold War led to the withdrawal of the Russian Federation military forces from Central and Eastern Europe and, after the process of sociopolitical transformation started in Poland in 1989, a debate was initiated on the legitimacy and effects of Soviet/Russian soldiers having been stationed in the country for several decades. ${ }^{1}$ The final withdrawal of the Russian Federation soldiers from Poland took place on September 18, 1993. The process of the withdrawal of the Russian Army began with the exit of the tactical ballistic missile brigade from Borne Sulinowo on April 8, 1991. In the first quarter of 1990, a commission chaired by Deputy Prime Minister Leszek Balcerowicz ${ }^{2}$ evaluated the initial losses resulting from the stationing of the foreign military forces in Poland. The analysis conducted at that time demonstrated that 
the largest economic losses were caused by: 1) the free access that soldiers of the Northern Group of Forces of the Soviet Army (NGF SA) (later, the Russian Army) had to the agricultural and forest land (military training grounds, airfields, artillery ranges, etc.); 2) non-compliance with the Polish laws related to environmental protection; and 3) the use of residential buildings and other structures (Krogulski 2001: 181). ${ }^{3}$

After 1993, mass media and scientific publications repeatedly released the following information:

In many places... after the Russians' departure the landscape resembled a battlefield. Roofs were ripped off the buildings, doors and window frames were devastated, window panes were smashed, radiators, bathtubs, toilet bowls were removed, even the high voltage lines were pulled out. Everything that had any value had been stolen and sold at markets or taken away to Russia. The rest, being useless, was barbarously ruined. (ibid.)

Although such descriptions were not entirely unfounded, the reality of the situation was more complex.

In this article, I analyze the problems related to the legacy left by the Soviet/ Russian soldiers on the former military bases in Poland, based on the example of Borne Sulinowo. This settlement, located in northwestern Poland (in the West-Pomeranian Voivodeship), was one of the largest and strategically most significant staging centers of NGF SA soldiers in Poland in the years 1945-1992.

The history of Borne Sulinowo is usually divided into several stages: the German civilian settlement Linde (from the sixteenth century to the 1930s), a German garrison (1933-1945), a Soviet garrison (1945-1992), and a Polish civilian town (from 1993 until now) (see Demski \& Czarnecka 2015: 96-120; Czarnecka 2015: 21-40). ${ }^{4}$

My aim is to reconstruct facts, opinions, and myths related to the "degraded" landscape of the former military base (I will return to the concept of degradation below ${ }^{5}$ ) through a juxtaposition of two perspectives. The "outside view" is related to narratives which emerged on supra-local levels and, in order to piece them together, I draw on information that appeared in the Polish national and regional press in the first half of the 1990s. The "inside view" is connected with the bottom-up experiences and memories of the inhabitants of Borne Sulinowo, and I recall them on the basis of interviews conducted in the field. ${ }^{6}$ From the point of view of the present analysis, yet another important source that often juxtaposed both perspectives, was the local newspaper Moreny: Gazeta Krainy Jezior i Lasów (Moreny: The Paper of the Land of Lakes and Forests), published in Borne Sulinowo in the years 1993-1996. ${ }^{7}$ 
Borne Sulinowo, located on Lake Pile and surrounded by forests, is often called "a forest town" or "the pearl of the Drawsko Lake District". Borne Sulinowo's location, with the town's natural and landscape values, is relevant from the point of view of the topic of degradation and environmental issues. It is a suitable example for exploring these issues.

In the text, I focus on the real and imagined problems that were related to the process of degradation of the landscape of the Soviet/Russian military bases in Poland, in an attempt to answer the following questions: What was the purpose of presenting the post-Soviet bases as "degraded" landscapes? What features were associated with such a type of representation? Does a "degraded" landscape contain in itself a capital that might be used in relationships with other agents? What were the strategies of presenting the foreign military forces on the local and supra-local levels in the context of the degradation process? Is a "degraded" landscape only a condition or is it also a way of seeing? In fact, the aim of this analysis is not to provide a description and an accurate inventory of the actual scope of damages and contamination, but rather to attempt to present the multidimensionality and relativity of the phenomenon of degradation in the context of the landscape of a former military base. "Degradation" reveals itself as a cultural construct.

\section{SOVIET GARRISONS IN POLAND: A HISTORICAL OVERVIEW}

In contrast to the allied forces, which after the end of World War II withdrew from the liberated territories, the soldiers of the Union of Soviet Socialist Republics (USSR) remained in Poland for over forty years. ${ }^{8}$ As early as June 1945, by order of Josef Stalin, a separate military structure was established under the name the Northern Group of Forces of the Soviet Army. Its existence was officially justified by the need to secure a back-up base for the Group of Soviet Forces in East Germany and transport routes between the USSR and Germany. Unofficially, each Soviet unit stationed in Poland was considered by Stalin to be a force which might support military operations in Western Europe (see Potyrała 1995: 117-127; Golon 1999: 37-115).

Until the early 1990s, the number, distribution, and type of Soviet units stationed in Poland was kept secret. At present, it is known that in the years 1945-1956 the number of Soviet soldiers in the country decreased from approximately half a million to less than 100,000. The agreement on the legal status of Soviet troops temporarily stationed in Poland was signed only at the end of 1956 , which means that in the years 1945-1956 NGF SA soldiers were stationed in Poland solely based on Stalin's personal decision. The breakthrough connected 
with the introduction of legal regulations was closely related to the turbulent events of the "Polish October" and the riots in Hungary. Nikita Khrushchev, who in 1953 assumed the office of First Secretary of the Central Committee of the Communist Party of the Soviet Union, was aware of the need to review the policy of the USSR towards "allied states" in Central and Eastern Europe.

The first legal regulations concerning the number and location of foreign troops were introduced on October 23, 1957, when the governments of the Polish People's Republic (PPR) and the USSR signed an agreement on the number, location, and procedure of movements of Soviet troops temporarily stationed in Poland. The document stipulated that the number of Soviet soldiers would not exceed 62,000-66,000, and that they would be located in thirty-nine garrisons (Fig. 1). ${ }^{10}$ In practice, there were many more garrisons and military units. The Soviets gradually decreased their number, reaching a level approximate to that stipulated in the agreement by the end of the 1980s. Their military garrisons were located (with a few exceptions) in the western part of Poland: in Lower Silesia, Western Pomerania, and Western Greater Poland (Krogulski 2001: 33-56).

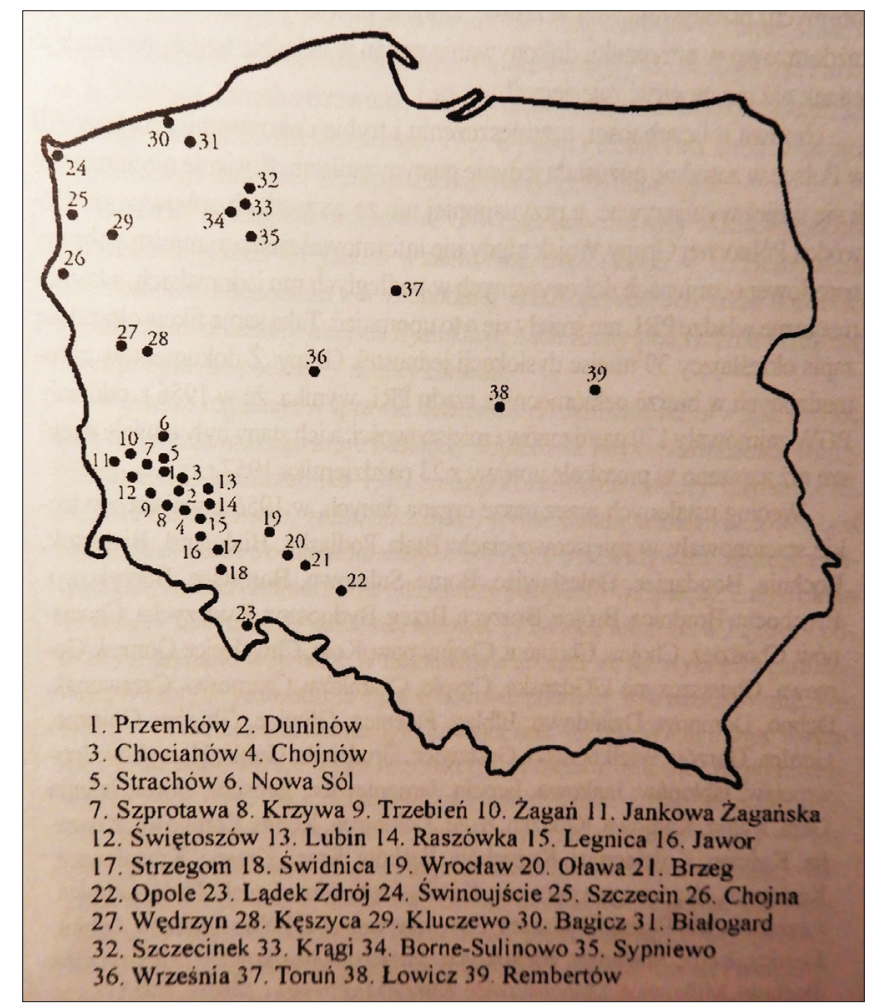

Figure 1. Thirty-nine Soviet garrisons in Poland. Archive URM. BPR, sygn. 2511/24 Vol. I. 
Although the German garrison in Borne Sulinowo was taken over by the Soviet Army in 1945, officially the soldiers of the 6th Guards Vitebsk-Novgorod Motor Rifle Division started being stationed there in 1947. In the Soviet military period, the location of the base among woodlands served mostly strategic purposes. For decades the military base was not marked on civilian maps, and one can read in Polish tourist guides about the time when the area near Lake Pile was inaccessible and unattractive. However, the secret settlement unit, apart from a railway line, had rather good road connections with major regional centers, such as Szczecinek (twenty-two kilometers) and Koszalin (ninety-five kilometers), and to the south, with Wałcz, Piła, and Poznań (Małachowski \& Szymańska 1994: 5). Until the time of the withdrawal of 10,000 Russian troops in October 1992, the whole area had an ex-territorial status and thus was excluded from the control and jurisdiction of the Polish administration. It is also worth mentioning that Soviet nuclear weapon depots were located in Brzeźnica, near Borne Sulinowo. ${ }^{11}$ For decades both the PPR authorities and the Soviet military denied the existence of nuclear weapons in Polish territory. Only in the early 1990s (at a conference held on April 7, 1991, i.e. the day before the first military units started to withdraw from Borne Sulinowo) was their existence officially confirmed by the commander of the NGF SA, General Viktor Dubynin. However, he did not specify their location at that time.

\section{“DEGRADED” LANDSCAPES AND PLACES}

In Poland in the early 1990s the concept of degradation was frequently used in the context of the post-Soviet bases by supra-local and local media. According to the Dictionary of the Polish Language, the verb zdegradować ('to degrade') has several meanings. In the context of the present analysis three of them are worth mentioning: 1) to cause destruction of the natural environment, 2) to decrease the value of something, and 3) to deprive of rank or dignity. Although the first meaning appears rather self-explanatory (it denotes all kinds of pollution and contamination of the ground, water, air, flora and fauna, with consequences visible or invisible, caused by human activity), the difference between the remaining two meanings may be somewhat unclear (and their semantic fields may overlap and complement each other). Therefore, I have used "the decrease of something's value" mostly in the economic sense. The result of degradation can be seen in a decrease in land value or real property prices, a lack of investors, the withdrawal of capital or decreasing interest in a place. The third meaning is related to the symbolic dimension and I understand it as a withdrawal or loss of a former position or role, the redefinition of meanings and concepts, or 
marginalization. In extreme cases, degradation may involve gradual destruction or even attempts at total annihilation.

Thus, the adjective "degraded" is assigned with negative value and is used to denote subjects/objects which have had the faith placed in them destroyed, applicable standards or patterns breached, or a specific function fulfilled but not up to outside expectations. More often than not, something suffering from degradation cannot be adapted to ongoing changes and, in effect, has to be "controlled" so as not to threaten the functioning of the orderly structure and development of self-reflexive systems with its distinctness. This distinctness is, then, perceived as a threat, a risk, something that needs controlling by way of warnings and prohibitions, something that is brushed aside, marked, limited, or suppressed. A reflection of this is seen in the synonyms of the verb "degrade" in the Polish language: to contaminate, to pollute, to poison, to destroy, to corrupt, to impoverish, to decrease the standard of something, to devalue, to depreciate, to beat, to defeat, to inflict heavy losses, to depose, to level down, etc.

Degradation does not happen naturally or by itself. Apart from the parameter of time, whose influence may intensify or limit the development of the process, and the effects of degradation, also present are the degrader and the degraded. Therefore, at least two sides are involved in the process of degradation, the sides being linked in the framework of a specific structure through various types of power relations. ${ }^{12}$ Moreover, within given hierarchies, the degrading side occupies a place at least one level above the degraded one. As degradation is based on belittling or even attempts at the elimination of what does not meet the imposed criteria, the process may be connected with the double mechanism of gratification-punishment (Foucault 1995 [1977]: 180-181). In the case of degradation, the weight is shifted towards the field of punishment. Representation of the opposite pole can be seen in a promotion, nomination, increase in rank, etc.

Change is written into the process of degradation (even if the degrading side assumes that degradation is ultimately aimed at preventing a change). Change, apart from being linked with various levels of structure, directly affects the degraded side, influencing its previous status, which decreases. As a result, the degraded side often becomes more vulnerable. However, imposing the need for reorganization and in the face of dealing with a new situation, instead of resulting in an intensification of the fall of the degraded side, degradation may lead to its discovering/triggering resources hitherto unknown, a reevaluation of meanings, and involvement in new networks and relations.

"Degradation" can be related to landscapes and places. For the purposes of this analysis, the notion of landscape is understood as a set of empirically defined objects, which are saturated with cultural myths and meanings, hidden convic- 
tions, and ideas of cultural seeing. Thus, landscape "implies a more-than-human materiality; a constellation of natural forms that are independent of humans, yet part and parcel of the processes by which human beings make their living and understand their own placing in the world" (Lund \& Benediktsson 2010: 1).

"Degraded" places, such as the ghost town Pripyat in Ukraine or Kłomino in Poland, generate specific landscapes, and have much in common with "countersites" (contre-emplacements) (Foucault 1984: 46-49). "Counter-sites" are places which contradict the spaces that surround them, forming a kind of dent in an ordered structure; they are estranged places, places which are distinct, which though they actually exist - remain, in a way, outside all routinely accessible and experienceable places. In effect, such places, or living in them, create(s) a sense of crossing a certain boundary, of entering "a different world".

In this context the areas of post-Soviet bases in Poland deserve special attention because, ever since they came into existence, they have exhibited numerous features characteristic of "counter-sites". For the majority of inhabitants, military bases resembled inaccessible islands which, despite occupying concrete physical space, existed on the margin of the known world, and were governed by their own rules. However, these places prospered, concentrating the tools of military power and more often than not becoming local centers of economic networks. Although the process of ecological degradation progressed, in the social imagination the areas of the bases were not perceived as "degraded" landscapes, for political reasons, which inhibited public debate, and because of a lack of access and actual knowledge about what was happening within their limits. Thus, while before 1993 the process of degradation was shrouded in mystery and restricted to particular aspects (especially ecological ones), the public (re)construction of "degraded" landscapes started after the withdrawal of Russian Federation troops from the bases. In spite of appearances, the process of creating and making known the "degraded" landscapes ought not to be limited only to the activities of NGF SA soldiers.

\section{POST-SOVIET BASES IN POLAND: RUSSIAN LEGACY}

Although the withdrawal of the NGF SA troops from Poland ended in 1993, the first serious movements of the armed forces began as early as the late 1980s, even before the official negotiations (Krogulski 2001: 169). On May 22, 1992, the Polish and Russian governments signed a package of agreements related to the withdrawal of Russian Federation soldiers from Poland. ${ }^{13}$ The "zero option" was adopted. It consisted of a mutual renunciation of property rights and financial claims, and ultimately ended all existing agreements with Russia. 
From the financial point of view, adopting the "zero option" was not beneficial for Poland as it meant that the state would have to pay for all ecological and material losses caused by the NGF SA troops throughout the period of their being stationed in Poland. On the other hand, it was the only chance for an earlier withdrawal of Russian units from Poland, because otherwise their evacuation would have only started after the withdrawal of the Western Group of Soviet Forces from Germany. In total, the losses incurred by Poland due to the stationing of Soviet/Russian military troops were estimated at 62.8 billion PLN (according to 1993 prices), out of which the "zero option" accounted for 62.3 billion PLN (Zdzisław Ostrowski, quoted by Krogulski 2001: 188). The total costs of the ecological damage in the territory of all post-Soviet bases in Poland were estimated at 52.2 billion PLN (according to 1994 prices), and in the territory of the Borne Sulinowo training area itself at four billion PLN (Krogulski 2001: 184; Pomysł na Borne 1994).

As far as taking over the mienie pojarowskie (the property left by the Russian Army units), Poland adopted a decentralized system: all of the property, as the property of the State Treasury, was immediately handed over to the respective province governors, who from then on were fully in charge of the development process. ${ }^{14}$ Apart from financial problems related to the transfer of the property to its new owners, there were initially no laws regulating this process. The relevant law on the redevelopment of real property of the State Treasury regained from Russian Federation military forces was only adopted on June 10, 1994, with later amendments. The Council of Ministers established a multi-annual program entitled "Redevelopment of recovered property and areas degraded by military troops of the Russian Federation". The program assumed that in the years 2001-2007 the state budget would provide grants from the special budget reserve to local governments and other entities in order to speed up damage liquidation and finalize redevelopment of the property taken over from the Russian Federation military troops. Borne Sulinowo was one of the municipalities that benefited from this program. Although some additional sources of financing were also found (e.g. European programs), to date (2016) the areas of the former military bases have not yet been fully redeveloped and reclaimed.

\section{“DEGRADED” LANDSCAPE OF BORNE SULINOWO: OUTSIDE VIEW}

When one reaches Borne Sulinowo, located among forests, away from other settlements, one has an impression of having crossed an invisible border. Although at first glance the town appears ordinary, after a short while the 
increasingly distinct shapes of uninhabited houses, dilapidated buildings, squares leveled to the ground and bearing traces of the recent presence of something more, and knife-like spikes of broken windowpanes bent into some pattern of a structure-striving organization, begin to give rise to anxiety and prompt questions (Figs. 2 and 3). Such sensations intensify upon arrival in nearby Kłomino (Gródek), whose scattered remnants do not induce any hope for the future (Fig. 4). ${ }^{15}$

However, in the early 1990s Borne Sulinowo looked completely different than at present. Surrounded on all sides by a high wall (which was later demolished almost entirely), it was rough and gray, as befits a former military garrison. After the withdrawal of Russian Federation soldiers from Borne Sulinowo in October 1992, Polish Army (PA) units were installed there for several months. ${ }^{16}$ Their goal was to protect the property from looters and vandals. At that time, the area of the garrison was only accessible on presentation of special passes. After the transitional period, Polish soldiers left the former Soviet base and the garrison was transformed into a civilian town, whose official opening took place in June 1993. PA soldiers also protected the property left over in Kłomino, a small settlement formerly housing Soviet/Russian military forces, located twelve kilometers away from Borne Sulinowo (Gródek bez żołnierzy 1993). ${ }^{17}$ Apparently, the presence of Polish soldiers in Borne Sulinowo failed in its purpose, as in September 1993, during the discussion on the issue of redevelopment of

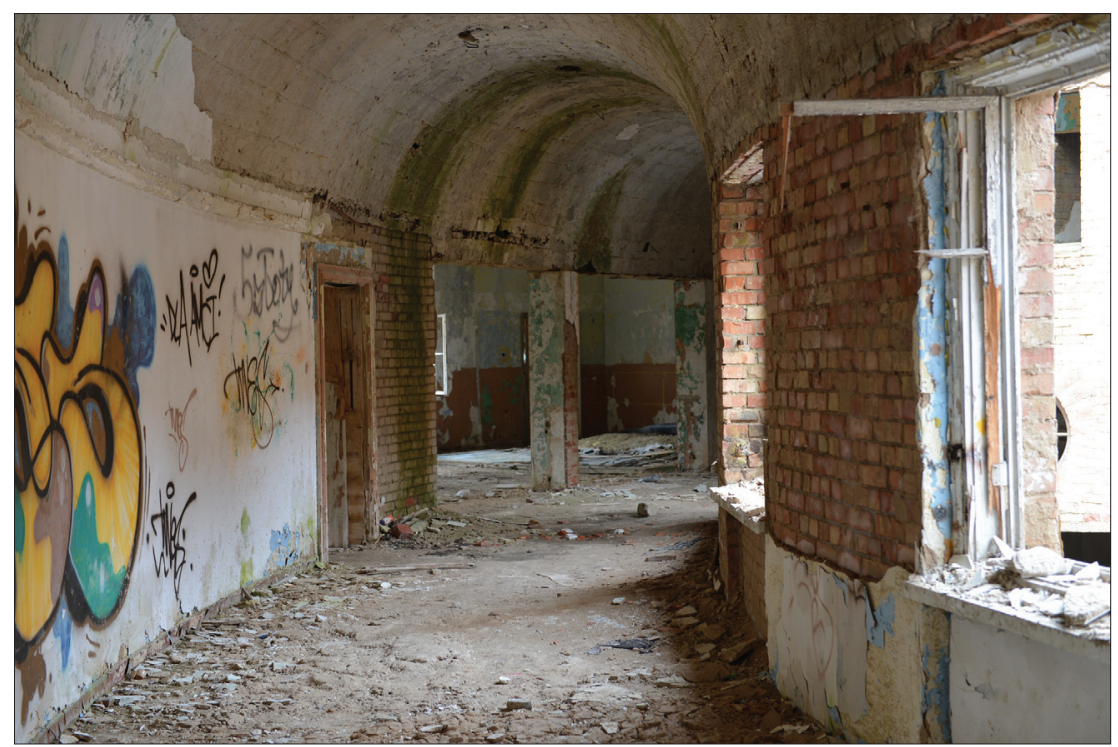

Figure 2. Degraded landscape in Borne Sulinowo. Photograph by Dominika Czarnecka 2015. 


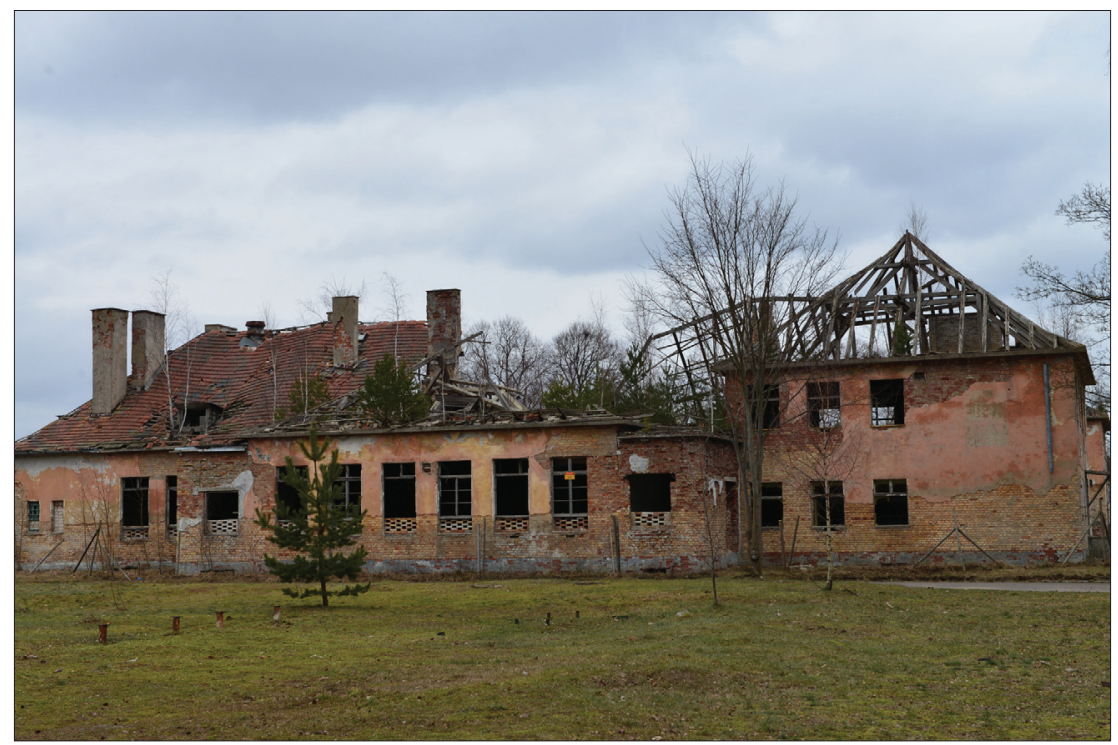

Figure 3. Degraded landscape in Borne Sulinowo. Photograph by Dominika Czarnecka 2015.

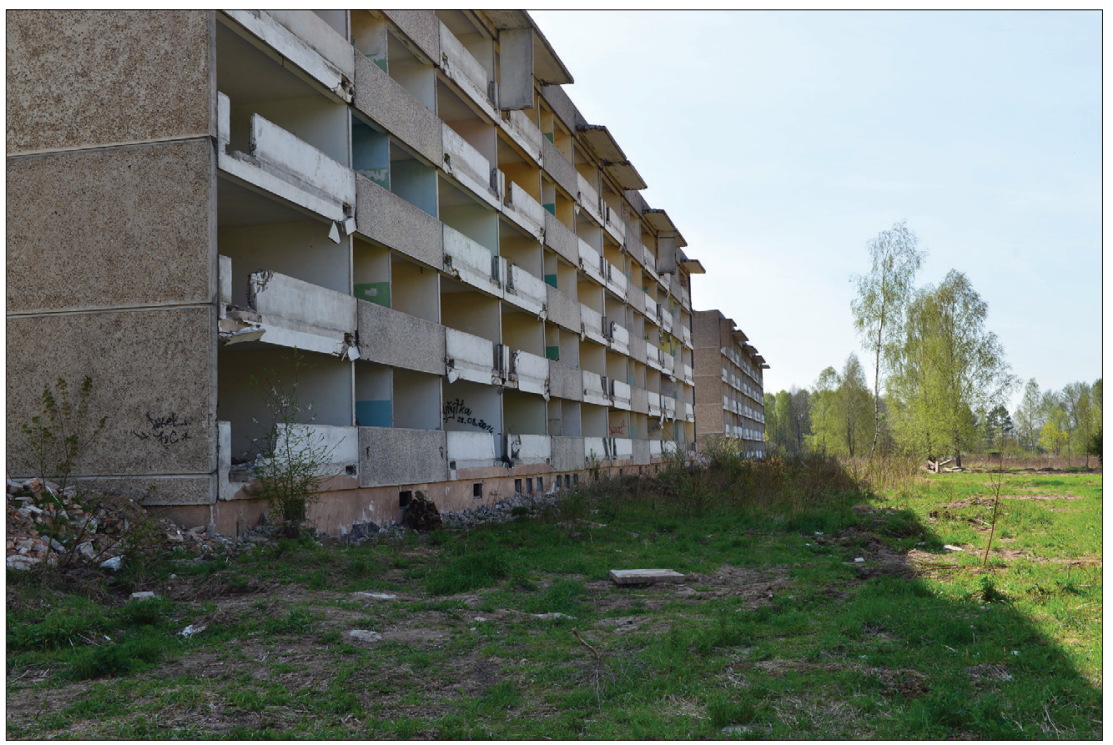

Figure 4. Kłomino. Photograph by Dominika Czarnecka 2015.

Kłomino, where "the Russians left several residential blocks and the devastated garrison buildings" (Sztyler 1994: 15), it was mentioned that effective measures were needed "to prevent damage and theft of property which, unfortunately, had been taking place in Borne Sulinowo" (Gródek do wzięcia 1993). 
In January 1994, Moreny republished a feature (translated into Polish) by Los Angeles Times journalists who had visited Borne Sulinowo in 1993. The descriptions they compiled represented the outside view. The article showed the former military base as "the land of chaos and great opportunity, where the security carries loaded guns and the residents enjoy their spare time in a bar named 'TEMPTATION'. ... Borne Sulinowo used to be considered the busiest base in Eastern Europe. ... But when the Russians left a year ago, the area of 70,000 square kilometers that constituted Borne Sulinowo was in ruins... What is worse, Russian soldiers robbed the base of everything that represented any value - from toilet bowls to telephone cables and commemorative tombstones. Whatever they left was looted by gangs of thieves who were stealing radiators, bathtubs and doorframes by the truckloads. Now, homesteads that were locked or hastily bricked up are guarded by the security carrying guns tucked into their belts..." (Murphy 1994: 4).

Although the article described a wave of pioneers flowing in from all over Poland and their endeavors to begin new lives in Borne, in reference to the base it contained such phrases as "grown wild after the Soviet Army had left", or "management of the ruined property" (ibid.). Moreny also republished articles from nation-wide newspapers, which contained descriptions related to the former base and Soviet/Russian soldiers. For instance, a journalist from the Nie weekly said:

Departing into the unknown eastern future, the Soviet soldiers palmed off to local peasantry all that could have been taken away, carried out, poured off. It started with the fuels and only the empty containers were left ... Then it was the turn for radiators, floorboards, water closets, bathroom tiles, and even doorknobs. (Pisali o nas 1995)

On the other hand, Gazeta Polska wrote:

The locals know all the forest paths. They took them to go trade with the Russians. ... We made do. When they went away, we went to take what was left behind. It belongs to us, not to those new settlers. An inheritance, so to speak. (ibid.)

As far as the ecological condition of the base is concerned, in the Soviet military period it remained entirely unknown to the Polish administration. This is why immediately after the withdrawal of foreign troops from Borne Sulinowo, agencies of the Polish administration ordered essential measurements related to the state of the natural environment to be conducted. The research was led by, among others, a group of Polish experts from the Wojskowa Akademia Techniczna (WAT) ('Military University of Technology'), together with a group of German specialists from Dortmund, acting within the framework of one of the 
ecological commissions of the Council of Europe. WAT's final report indicated that the town was free from pollution and contamination (Rząd 1994). The norms for acceptable pollution/contamination were exceeded, however, near fuel depots, chemical training grounds, chemical warehousing facilities and waste storage facilities (Sa czy 1993). ${ }^{18}$ The ecological condition was one of the basic determinants of introducing civilian settlement in the area of the base. The press reported "increasingly better, fantastic even, results of the tests. The place started to be compared with the cleanest regions of Europe" (Rozgoryczenie 1994). Thanks to the satisfactory results of the tests, in Borne Sulinowo the idea was conceived to create "green schools" for children from ecologically endangered areas. According to the statements issued then by the local authorities, the endeavor was to become a driving force for the future development of the town (Szpindor 1992: 5). Ultimately, the idea was not put into practice. Although there were at least several reasons for that, in the context of the present analysis it is worth mentioning the change in the supra-local narratives.

Despite the fact that as soon as the end of 1993 the media started to mention possible contamination with increasing frequency, the real change came with the report compiled by the chief inspector of environmental protection in 1994, entitled "Identification and evaluation of ecological damage caused by Russian Federation Forces stationed in Poland" (the report contained descriptions of all of the post-Soviet military bases) (Kamieński et al. 1994). On the basis of this report, it was announced that decontamination of the destroyed areas "will take... several dozen, or even - in certain cases - several hundred years" (Borne w dokumentach 1995; Koszty przyjaźni 1993). The most polluted places mentioned in the report were Brzeg Opolski and Borne Sulinowo. The data contained in the report was quickly widely publicized by the national Polish media. Journalists started to inform the public about all possible and imagined types of contamination, infection, and pollution. In April 1994, Polish Television and newspapers, such as Gazeta Wyborcza (national) and Trybuna Śląska (regional), spread information about the "Lost Land" (Ekologia 1994). After a press conference of the chief inspector of environmental protection, Andrzej Walewski, Gazeta Wyborcza wrote that in Borne Sulinowo "an underground river of oil and chemical waste is flowing towards the lake" (Karkoszka 1994: 8) and published a "death map", which was later republished by other media. Such expressions as "death zone", "lost land", and "Little Kuwait" started to circulate. However, pieces of information published by the media were inconsistent, often contradictory. Numerous journalists, some of whom had never been to Borne Sulinowo, wrote such reports to cause sensation, attempting to join in the antiRussian discourse on a supra-local level (see Czarnecka 2015: 21-40). The Board of Green Schools Foundation (a supra-local body) announced in relation to the report of the chief inspector of environmental protection: 
Even if the data contained in it prove imprecise after more in-depth analyses and studies, this will not change the fact that Borne Sulinowo will be associated with a death zone, a place to which no parent would send their child to a green school. Therefore, this report is a final blow to those operations of the Foundation which were to lead to creating such a center. (Rozgoryczenie 1994)

Apart from the information on chemical contamination, in the early 1990s the media often made references to radioactivity and unexploded ordnance. As far as radioactivity is concerned, no research confirmed such a threat. Meanwhile, the press repeated gossip about fluorescent mushrooms and dying fish, which was highly evocative, especially in the context of the relatively recent Chernobyl nuclear reactor accident (1986) and the images of the deserted, ecologically degraded Ukrainian town of Pripyat. The following excerpt provides a relevant example:

Allegedly, in the woodlands of the training ground there is a 'death zone', where no civilians have ventured for years. In the early $1980 \mathrm{~s}$ a scrupulously concealed 'accident' took place there and that is why some of the contamination in this region is supposedly radioactive. (Ktokolwiek wie 1994)

The local population treated such revelations as an attempt to sensationalize, which was expressed in the local press:

Radioactive scam. No one in Borne Sulinowo is afraid of either radioactive or chemical pollution. 'I don't know where the gossip on Borne's contamination comes from. I heard those stories about the lake polluted with phenol and about people whose hair fell out after a visit to Borne. But this is not true', the parish priest explains. The others, asked if they are not afraid to live there, tap the side of their heads or grumble about the press which has, until recently, written at length about the radioactive pollution in Borne. (Łazarewicz 1993: 4)

The problem of unexploded ordnance and the costs of land re-cultivation were also frequently discussed. One of the 1993 press articles contained a commentary related to the military training grounds in Borne Sulinowo:

We [a journalist from the supra-local newspaper and foresters - D.C.] reached this place through devastated forests, full of trees broken by shells and evidence of fires which happened several times a year. The Russians did not always allow our firefighters and foresters to conduct firefighting and rescue actions. (Karkoszka 1993: 5) 
At the same time, apart from information related to the threat of unexploded ordnance and clearance operations, ${ }^{19}$ the article mentioned the process of reforestation and the costs of re-cultivation operations, amounting to an average of 11.5 million PLN per hectare. A member of the National Forests staff told the newspaper:

We are planting pines, oaks, and birches. This land had been waiting for that for dozens of years. So far, the seedlings have grown like crazy. There, look at how green it has already become, and only two years ago there was only sand there. Plants, animals, and birds are coming back. (ibid.)

Newspaper Stowo Polskie wrote that the Soviet/Russian military forces were not held responsible "for instance, for ecological losses which they caused on the territory of our country. ... It will take time before nature will effectively help us heal these wounds; it will also take time before man can accomplish something here" (Pisali o nas 1995).

The Soviets/Russians were named as those who had caused the ecological damage, which was quite true, yet it was also stated that, as a result of the "zero option", it was impossible to force the Russians to finance any of the recultivation of the natural environment.

Meanwhile, there is no doubt that the withdrawal of the Russian Federation soldiers from Borne Sulinowo and the perception of the landscape as degraded influenced the attitudes and actions of people who arrived in Borne Sulinowo with no intention of settling in the town. Especially during the first stage, they plundered and destroyed items left by the Soviet/Russian soldiers. However, the ecological degradation of the post-Soviet base was not increased (e.g. no illegal garbage dumps were found), which was certainly influenced by the quite quick process of settlement in this territory and efforts of local governments.

The majority of Borne Sulinowo inhabitants did not believe the revelations published by journalists from the supra-local media, a fact which is shown, for instance, by the low percentage of residents who left the town. However, on the local level it became noticeable that such commentaries had negative effects on the development of the town, which was only beginning to organize itself. The inhabitants of Borne Sulinowo issued an official protest to the authorities of the province (List otwarty 1994). In order to placate them, a meeting with the provincial environmental protection inspector was arranged in the town. With regard to the 1994 report, it was stated that the differences in the assessments of the situation were probably caused by changes in research methodology and contamination limits (which were made stricter) (Małolepszy 1995: 8-9). 


\section{"DEGRADED" LANDSCAPE OF BORNE SULINOWO: NATURAL ENVIRONMENT. INSIDE VIEW I}

The interviews I conducted with the inhabitants of Borne Sulinowo in 2015 and 2016 on the subject of the degradation of the post-Soviet base and the personal attitudes of the settlers towards what happened there in the early 1990s reveal a slightly different picture of the reality of the time than the one presented on the supra-local level. Yet, it is worth noting that the interviews were conducted over twenty years after those events had taken place. In fact, it is necessary to remember that past decisions, opinions, and attitudes of Borne Sulinowo inhabitants find additional support in the fact that throughout the period of the civilian town's functioning no ecological disaster has taken place, there have been no serious incidents of contamination or diseases, and the town has become one of the best known and fastest developing post-Soviet settlements in Poland.

The majority of people who decided to come to Borne Sulinowo at the beginning of the 1990s were mostly driven by housing-related considerations (similar houses or flats in other regions of Poland, if available, cost at least two or three times more at that time), together with an opportunity "to start everything anew". As a rule, new settlers had no knowledge of the former military base because even those who came from the surrounding settlements did not have access to the garrison town in the period when the Soviet/Russian forces were stationed there (apart from a small number of specialists). In this sense, all of them entered an unknown region.

As far as environmental degradation is concerned, the majority of the newcomers did not worry that the area of the former military base presented a risk to life or limb, having assumed that since the representatives of state governments decided to establish a civilian town and encouraged its settlement, experts must have conducted the necessary measurements and that it was safe there. There were some whose experience suggested that some threats might be present in a post-military area, but they accepted this possibility and took the risk in the name of new opportunities:

I realized that after forty-seven years of military presence here all kinds of surprises might come up related to unexploded ordnance, maybe some ground contamination. ... I was aware of that. ... You know, I wished to do things my own way... ${ }^{20}$

On the local level, reactions to the subject of contamination varied. Some "people were simply afraid, it was natural, nothing surprising about it", ${ }^{21}$ yet only in a few cases did this fear lead to leaving the town. Among those who stayed in Borne Sulinowo, various strategies were employed. Some did not believe the 
information which appeared in the mass media, claiming that journalists were only sensationalizing. Some were not interested in matters which remained outside their everyday existence. Others trusted the decisions made by the representatives of state agencies: "I simply have faith in those who rule here.... If it is possible to live here, they must know it is possible...", ${ }^{22}$ their own direct experience (e.g. observation of plant and animal life) contradicted media revelations, or they found information in sources they considered more credible:

[A]t that time the authorities and the military assured us that there was nothing here that would endanger our lives... I also had an opportunity to meet officers of the former Russian Federation... and they also claimed... that 'we lived in the town with our families and we wouldn't allow our own families to be poisoned'. And this is convincing. ${ }^{23}$

Media reports circulated on the supra-local level had negative consequences for the development of the local community, for instance, in the context of the development of tourism, which formed one of the basic income sources for Borne's inhabitants. There was difficulty in gaining new investors. One of the inhabitants of Borne Sulinowo stated:

[T] he press did not favor us, when you think of those first years of development of Borne Sulinowo, and neither did the rest of the media, and it is those all-Poland media that very much disfavored us. I don't know why. ... Of course, we tried to present Borne Sulinowo in the best possible light, its 'tourist potential'... We were always shown as a former military base, a contaminated, degraded place. And since then we have been just a little prejudiced towards the media...24

As it later turned out, some information related to environmental pollution (e.g. contamination of Lake Pile waters with phenol and mercury) was purposefully made up by competitors in the tourism and recreation sector, since Borne Sulinowo, surrounded by forests and lakes, had quickly built up its position as a tourist attraction of the region (Potwór 1994).

It is also worth mentioning that even now at least some inhabitants of Borne Sulinowo are afraid that when the Russian Federation soldiers were withdrawing from Poland, they might have hidden somewhere on the base something that would be hazardous and difficult to handle (e.g. chemical weaponry). Foreign soldiers could have poured concrete over such waste somewhere underground, which would make it a ticking time bomb. As these types of scenarios remain mere suspicions, they say more about the attitude of the Poles to Soviet/Russian soldiers than about the actual state of affairs. 
Summing up this sub-chapter, it is worth noting three points. Firstly, the inhabitants of Borne Sulinowo believed that although NGF SA soldiers living there did not respect the natural environment, they did not degrade it consistently or with determination. Secondly, the settlers were in agreement as to the fact that Soviet/Russian soldiers were responsible for ecological damage on the former base. And finally, the inhabitants did not agree to the image of the former military base, constructed on the supra-local level, as an ecologically degraded place.

\section{“DEGRADED” LANDSCAPE OF BORNE SULINOWO: BUILT ENVIRONMENT. INSIDE VIEW II}

In the early 1990s, Borne Sulinowo looked different than at present. The local press repeatedly published the memories of the first inhabitants of Borne Sulinowo, which painted a picture of the youngest Polish town of the time:

It was a strange town, completely different from what it is now. Empty, alien and menacing! ... Empty houses, windows boarded up and padlocked doors, a haunting sight... Broken furniture, suitcases, containers left by the Russians scattered around the buildings. Abandoned, ravenous dogs and feral cats were wandering among the deserted blocks of flats. And something 'ever-present' - the stench, that horrible stench! ... Sleeplessness intensified by thuds of doors being pulled out of their frames and padlocks torn off. Thieves didn't sleep that night either, and not just that night! Municipal workers could hardly keep up with installing new padlocks... And the soldiers? They sat in their guardhouses... (Poczobutt 2003: 28-29)

What is significant is that descriptions of this sort did not concern the state of the base right after the withdrawal of the Russian soldiers - a fact rarely noted. They were usually related to the stage after the end of the transitional period, when the garrison was already under the supervision of the Polish Army. According to the substance of the interviews conducted with people who arrived in Borne before the town was officially opened, despite the concerns of the Polish authorities the foreign soldiers devastated neither the structures in a way that could limit the town's functioning (e.g. the main boiler plant, water treatment plant or ester supply system) nor the remaining buildings (they closed off numerous buildings before they left). In the opinion of many inhabitants of the post-Soviet base, most of the damage in Borne Sulinowo was done by Poles themselves: 
It's not true that the Russians destroyed [everything]; the Poles did. I used to live in Kragi ${ }^{25}$ and the Poles carried away various things using tractors. ... I'm not saying that they were from Kragi only, [but] from the whole municipal area. ${ }^{26}$

There were hordes of thieves here, who devastated the town; all metal elements were torn out. The municipal government, so as to rescue at least something, had the heaters taken out... ${ }^{27}$

One of the settlers, a specialist who was present on the base when the Russian Federation troops were leaving it, claimed that in the final phase several soldiers who did not want to leave Poland tried to hide on the base. A search began and possessions were thrown out of the windows of the searched flats:

Then, when they were showing Borne on TV, there was always this pile of broken furniture in front of and next to the buildings, because there were three buildings there, and there was this whole row of furniture somewhere up to above the first floor. ... And another site was the junkyard, a couple of hectares of it. And always, if it was about Borne, then there was this junkyard and this broken furniture. Such was the image of Borne then. ${ }^{28}$

Therefore, although the Soviets/Russians constructed on the site of the base many objects which did not meet the required norms of the Polish construction law (later it was necessary to reconstruct or demolish them, which in both cases required substantial financing), and the road infrastructure was in terrible condition as a result of heavy vehicle traffic, in the opinion of the majority of the first settlers, the degradation of the built environment of the former Soviet base was mostly the fault of Poles. This does not in any way alter the fact that damages inflicted by the armed forces stationed there, together with the failure to observe the norms and standards applicable in Poland by NGF SA soldiers, led to lowering the value (including economic) of the property of the base, and to changes in its landscape. The property, which was left unattended and without adequate funding after the withdrawal of the Russian Federation forces, was either devastated by vandals or gradually fell into ruin, additionally decreasing the value. As a result, the process of degradation continued. One of the most dramatic examples of this process is Kłomino, where degradation affected the whole area of the settlement (Sztyler 1995: 12-13). 


\section{STRATEGIES OF PRESENTING SOVIET/RUSSIAN SOLDIERS IN THE CONTEXT OF THE PROCESS OF "DEGRADATION"}

At the onset of the 1990s, the condition of various levels of political, administrative, and economic structures in Poland (the bare bones of the main structure are made up of little sub-structures, e.g. post-Soviet bases) may be described as being in transition. In such a stage all attributions of danger and power are manifested much more distinctly than in normal circumstances. Activities related directly or indirectly to "degraded" landscapes on the former Soviet/ Russian bases reflected the process of revision of the norms, relations, functions, and boundaries within the main structure. Although individual levels of a structure may differ from one another, it is worth noting that they never remain completely isolated, but overlap and supplement one another.

Various strategies of presenting Soviet/Russian soldiers were used in the narratives on Borne Sulinowo (both on the supra-local and local levels). The soldiers could be presented as "main characters of the story" or as agents of certain activities that shaped the degraded landscape of the post-Soviet bases. In the latter case, alien soldiers were presented indirectly (through descriptions of the base), which does not mean that the descriptions were less effective.

As a rule, Soviet/Russian soldiers were shown as responsible for ecological damage, and therefore as having undertaken actions that destroyed the natural environment or blocking initiatives which could have prevented the negative effects of such degradation. Their agency was connected with an essential lack of responsibility (as a rule, emphasis was placed on financial responsibility) for the damages caused in a foreign, though "allied", country.

On the supra-local level, the message was at least partly directed at creating the sense of ecological disaster on the former military bases. Exposing pollution and contamination, issues which were juxtaposed with descriptions of rehabilitation work after Soviet/Russian soldiers' withdrawal from Poland, served to create "us"-"them" contrasts. While "they" were presented as undemocratic, exploitative, irresponsible, and so on, "we" appeared as co-operative, productive, and responsible guardians of land and natural landscape. In the context of contamination, foreign soldiers were presented as those who disturbed a certain order, as a source of chaos and problems, and this, in turn, was related to articulate and inarticulate powers vested in them. This was by no means an exclusively internal order, but global and universal, if we assume that natural landscape is heritage for future generations and that natural environment is humankind's resource (Milton 1996: 173).

As Mary Douglas aptly noted, disorder - just like formlessness - is destructive to existing patterns: "It symbolizes both danger and power" (2001 [1966]: 
95). Contamination is characterized by a lack of form, often intensified by its invisibility, as in the case of radioactive contamination. Pollution is a particular class of danger; yet, in order to perceive the significance of a specific threat in the context of a given community, it is necessary to place this threat within the whole range of dangers possible in any given universe, because "Some dangers are great and others small" (ibid.: 4). In the Western European context, environmental pollution, especially radioactive pollution, ranks high in the hierarchy of possible threats, and exists in a close relationship with dangerous power. Currently, the risk of an ecological disaster forms a recurrent motif of everyday life (Giddens 2010: 15).

The presentation of Soviet/Russian soldiers as a source of disorder was also related to opinions about the ways in which foreign soldiers treated movable and real property. In this respect, representations of Soviet/Russian soldiers were negative and one-dimensional, while the part played by Polish vandals and looters in the process of the devastation of the base was passed over or marginalized. Thus, both in the ecological context and from the point of view of lowering the economic value of the base's property, alien soldiers were seen as the degrading side. Presenting the base as a place grown wild and ruined reinforced the stereotypes and the images of Soviets/Russians as "barbarians from the East", who were a source of menace and destruction due to their power (in this case, military), and who treated the area of the Polish base as war plunder.

The strategies of presenting Soviet/Russian soldiers were different on the local level. Inhabitants of Borne Sulinowo, who were beginning new lives on the post-Soviet base and observed their surroundings daily, treated ecological issues in practical terms (a challenge that needed to be confronted). Although in the bottom-up narratives of the civilians there were accounts and recollections connected with illegal and environmentally abusive activities of ordinary soldiers (e.g. trade in fuel and blast fishing), the inhabitants of Borne Sulinowo saw the greatest threat as lying in the functioning of the Soviet Army, whose negative image they additionally stressed by juxtaposing it with the functioning of NATO forces. It cannot be excluded that the more moderate opinions toward the illegal activities of Soviet/Russian soldiers were caused by the fact that some inhabitants of Borne Sulinowo, born in the surrounding settlements, benefited economically from such practices.

With respect to the property left on the base (and its degradation), their judgments were also more varied and ambivalent, which is not to say that they were positive. Whereas the stress placed on the difficulties related to the process of settling the former garrison was a way of presenting the organizational difficulties with which new settlers had to deal, presenting the base as a degraded landscape was absolutely against the interests of the newly forming commu- 
nity. Thus, the representations of the base constructed top-down were received negatively on the local level, as they were in conflict with the bottom-up view.

It is difficult to resist the impression that the outside view was aimed at other ends than the image seen and presented on the local level. It was also directed at, and reached, if not a completely different audience, at least a much wider one. It is on that level that we can observe the influence of the third meaning of the word "degraded": its symbolic dimension. Within the strategy of presenting Soviet/Russian soldiers in the context of the landscape of a "degraded" post-Soviet base, employed on a supra-local level, a shift between the degraded and the degrading sides took place. This is because presenting the results of the activities of foreign soldiers (the degrading side) served to degrade them symbolically. Alien soldiers were placed in the role of the degraded side, whose status in the new context was altered or, more specifically, lowered. Depriving "Others" of their former position was a way of diverting a threat and securing the functioning of an ordered structure, but it also reflects changes in power relations. ${ }^{29}$

\section{“DEGRADED” LANDSCAPE: ACTUAL STATE OR A WAY OF SEEING?}

Although at the onset of the 1990s nearly all post-Soviet bases in Poland were presented on the supra-local level as degraded and ruined landscapes grown wild, after more than twenty years, since the final withdrawal of Russian Federation forces from Poland, it is possible to notice that time treated some places mercilessly, while others were spared. Borne Sulinowo used the change to its advantage and, despite having initially functioned with the stigma of a "degraded" place, it underwent a reorganization which led to discovering new resources, including settlement in new networks and changing its own status. Helpless Kłomino, on the other hand, remains an embarrassing reflection of a "forest town", embodying the chaos of a battleground and transforming its former status of "counter-site" into an extreme shape. Borne and Kłomino reflect the interplay of ideas of form/order and formlessness/disorder. Yet, even today there are ruins, uninhabited houses and the stigma of everyday uselessness in Borne Sulinowo.

John Berger claimed that "the way in which we perceive things depends on our knowledge or faith" (2008: 8), and that "looking is an act of choice" (ibid.). "Degraded" landscapes may be treated as more than just actual reality. They may be treated as specific ways of seeing, different depending on who is looking, what is paid attention to, and what goal is related to this act. The case of 
Borne Sulinowo makes it possible to notice that the basic differences in seeing resulted from the levels on which particular narratives were constructed: local vs. supra-local, outside vs. inside views. The point of view of a Borne Sulinowo inhabitant, who experienced the environment of the former base daily and in its entirety (e.g. the natural environment, the ruins, and other post-Soviet remnants) with all of the senses, was certainly different from the point of view of a central government politician or a national media journalist. The differences resulted not only from dissimilar interests and experiences, or different knowledge of the place, but also from Berger's concept of "faith". Equipped with that faith, new settlers did not perceive the Soviet base as a "degraded" landscape, but rather as a potential, an opportunity. It seems impossible to live and build on land which one personally perceives as "degraded". Such a way of seeing is a negation of the faith and hope indispensable for triggering agency.

From the supra-local perspective, presenting the post-military Soviet space as "degraded" was related to the process of symbolic conversion. After the change in status, after the marginalization and reduction of its value, a process of including that sub-structure in the main structure began, while viewing it as something different. Nicholas Mirzoeff remarked that "visual culture is a set of relations between what is visible and the names which we give to what is seen" (2016: 25). Ecological degradation may also be perceived as a specific way of seeing, manifesting itself in the form of diversified and changeable norms and methods of pollution measurement. Examples illustrating this multidimensionality, but also the perfidiousness of seeing in this particular case, were the changes in the interpretation of ecological conditions of Borne Sulinowo caused by the publication of the report of the chief inspector of environmental protection in 1994.

Ruins, meanwhile, are not an invariable and unquestionable indicator of an ongoing process of degradation. They involve a way of seeing that determines whether a dilapidated building will represent to its viewer the quintessence of a fall or an object of fascination related to the "ruin gaze" ${ }^{30}$ From this perspective, the inside view and the outside view are supplemented by the "romantic" view of tourists and other outside visitors who seek aesthetic qualities and thrills in "degraded" landscape. For people who arrive in Borne Sulinowo and participate in such activities as paintball, treasure hunts or the International Rally of Military Vehicles, seeing the post-Soviet base as a ruined place is attractive (in contrast to the general outside view). Interviews with inhabitants of Borne Sulinowo revealed the dilemma of whether to live in a more aesthetic, renovated, and modern built environment or to preserve the original features of the military garrison. The ruins and the atmosphere of mystery created by them are an important tourist attraction in the region, which is a source of income 
for at least some local settlers. Therefore, the attitude of the local community to ruins and other post-Soviet remnants is diversified, based on the role they play in the process of achieving personal aims.

If we assume that degradation is a way of seeing (at least to a certain extent), then "degraded" landscapes become forms which are relative, changeable over time, and culturally constructed.

After the final withdrawal of the Russian Federation soldiers from Poland, dozens of "degraded" landscapes (which until the early 1990s were invisible both literally and metaphorically) suddenly appeared. In the context of the above reflections, the question arises as to the extent to which their status represented actual reality or was a way of seeing, a cultural construct written into the sociopolitical context of the time, a need to react to over forty years of foreign troops' presence in Poland, stereotypes related to Soviets/Russians or, finally, the extent to which the "degraded" landscape reflected the relationship between Soviet/Russian armed forces' legacy and ourselves. Both the outside and the inside views were adopted standpoints and specific ways of understanding the world, while "degraded" landscapes constructed on the supra-local level formed integral building material of the reality of the time, appearing as repeated structures connected with organizing the community under new principles. Finally, in the early 1990s, the "degraded" landscapes of the former military bases in Poland fulfilled specific tasks on at least two levels: the more obvious one was largely instrumental and the other one was expressive.

\section{NOTES}

1 When I use the term "Soviet soldiers", I refer to the soldiers of the Northern Group of Forces of the Soviet Army (NGF SA) (1945-1992). When I use the term "Russian soldiers", I refer to the soldiers of the Russian Army (1992 till now). When I refer to the whole period of the stationing of foreign forces in Poland, I use "Soviet/Russian soldiers".

2 Deputy Prime Minister and Minister of Finance in Tadeusz Mazowiecki's government in 1989-1991.

3 The data quoted by Mariusz Lesław Krogulski came from the progress report of the working group for the cost analysis of Soviet military forces stationed in Poland, dated March 30, 1990.

${ }^{4}$ I have described the history of the military base in Borne Sulinowo in more detail in earlier publications. These papers are related to the subject matter with which the present analysis is concerned; in fact, they complement one another. Wishing, on the one hand, to avoid unnecessary repetition, but on the other hand aspiring to cohesion and clarity of the following part of the argument, I have indicated in the text the issues which were described in the previous publications only when necessary. 
5 I have put the adjective "degraded" in quotes when it is used in the word's multidimensionality. Otherwise, I have used the normal notation.

6 I carried out my research in Borne Sulinowo in February, May, and August 2015, and in May 2016. I conducted nearly thirty in-depth interviews with the town's inhabitants (the "snowball technique" was used to find new respondents). I used the method of participatory observation and performed a search of local press and source materials collected in the private archives of the manager of the Museum Chamber in Borne Sulinowo.

7 As a local newspaper, Moreny employed journalists from Borne Sulinowo and its surroundings. I have treated their viewpoint, together with that of the accounts of the town's inhabitants (e.g. protests, letters, and commentaries) as elements of the inside view. Additionally, Moreny often republished articles from national and regional press, related to Borne Sulinowo and its vicinity, or to other post-Soviet bases. These resources have been treated as elements of the outside view.

8 As a result of the Potsdam Conference agreements of 1945, the borders of the Polish state were altered. Poland gained territories in the west from Germany, later colloquially called the "Recovered Territories"; in the East, however, it lost lands to the USSR, which formed over half of the pre-war territory of Poland.

9 "Polish October" is also known as the "Polish October Revolution" or "October 1956". After several demonstrations and tense negotiations, the Soviets gave permission for Władysław Gomułka (the leader of the reform faction in the Polish United Workers' Party) to stay in control, and made several other concessions resulting in greater autonomy for the Polish government. This marked the end of the era of Stalinization in Poland.

10 The Soviet military garrisons in Poland: 1. Przemków, 2. Duninów, 3. Chocianów, 4. Chojnów, 5. Strachów, 6. Nowa Sól, 7. Szprotawa, 8. Krzywa, 9. Trzebień, 10. Żagań, 11. Jankowa Żagańska, 12. Świętoszów, 13. Lubin, 14. Raszówka, 15. Legnica, 16. Jawor, 17. Strzegom, 18. Świdnica, 19. Wrocław, 20. Oława, 21. Brzeg, 22. Opole, 23. Lądek Zdrój, 24. Świnoujście, 25. Szczecin, 26. Chojna, 27. Wędrzyn, 28. Kęszyca, 29. Kluczewo, 30. Bagicz, 31. Białogard, 32. Szczecinek, 33. Krągi, 34. Borne Sulinowo, 35. Sypniewo, 36. Września, 37. Toruń, 38. Łowicz, and 39. Rembertów.

${ }^{11}$ Brzeźnica is located approximately thirty kilometers to the south of Borne Sulinowo. Jointly, there used to be three nuclear weapon depots in the territory of Poland. The remaining two were located in Templewo, near Trzemeszno, and in Podborsk, near Białogard (Szulc \& Nicpoń 2007: 62-77).

12 The term "side" is used conventionally here to denote individuals and groups, as well as institutions.

${ }^{13}$ Executive decisions for the adopted provisions were prepared in June 1992.

${ }^{14}$ A different solution was adopted in Germany, the Czech Republic, and Hungary, where the whole property formerly belonging to the Russian Army was taken over by the Ministries of the State Treasury, and the ministries themselves initiated the process of seeking new users (Czulicki 2014: 21).

${ }^{15}$ Borne Sulinowo, Kłomino, and the extensive military training grounds located between them made up the whole huge complex of the Soviet/Russian military base. 
${ }^{16}$ In the period between the withdrawal of Russian Federation troops from Borne Sulinowo and the decision to establish it as a civilian town, Polish authorities considered the option of transforming it into a garrison of the Polish Army.

17 The situation in Gródek was even more difficult than in Borne Sulinowo, as this was a military settlement separated from larger urban centers and lacking basic infrastructure essential for turning it into a residential settlement.

18 The research of the scientists from WAT covered 59,900 of the 70,000 ha of the total area of territories occupied by Soviet/Russian soldiers (in twenty-one places where they were stationed). There were 406 ha of land recognized as regions of ecological disaster (noxious waste stores, floating fuels, and chemical contamination). The report stated that Soviet/Russian soldiers devastated 38,100 ha of forests, 6,500 ha of ground water, 17.5 ha of surface water aquifers, and 15,300 ha of soil and vegetal layer (Kamieński et al. 1994: 15, 24).

${ }^{19}$ Information regarding the action of clearing mines from the post-military areas appeared in the press numerous times in the following years (Chabior 1992: 2; Min nie ma 1993; Wybuchowe Borne 1995). The operation of clearing mines from the training grounds in Borne Sulinowo ended in 2015, and was an effect of the implementation by the State Forests National Forest Holding (SFN FH) of the project "Re-cultivation for natural conservation purposes of the degraded areas, former training grounds, and post-military areas remaining under SFN FH management".

${ }^{20}$ Interview with D. Sz., Borne Sulinowo, May 2016.

${ }^{21}$ Interview with D. Cz., Borne Sulinowo, May 2016.

${ }^{22}$ Interview with D. K., Borne Sulinowo, May 2016.

${ }^{23}$ Interview with J. M., Borne Sulinowo, May 2016.

${ }^{24}$ Interview with D. T., Borne Sulinowo, May 2016.

${ }^{25} \mathrm{~A}$ village situated in north-western Poland. It lies approximately four kilometers northeast of Borne Sulinowo.

${ }^{26}$ Interview with D. K., Borne Sulinowo, May 2015.

${ }^{27}$ Interview with P. K., Borne Sulinowo, May 2015.

${ }^{28}$ Ibid.

${ }^{29}$ After the end of World War II, the western territories incorporated into the Polish state, which earlier belonged to Germany, underwent a process of constructing alienation towards Germans. It was in no way related to a "degraded" landscape in the context of the former German bases taken over by the Red Army, and it proceeded differently. This issue is worthy of another study and does not form a part of the present analysis; however, it demonstrates that "degradation" is a cultural construct.

${ }^{30}$ The ruin gaze "can be understood as the particular optics that frames our relationship to ruins. Contemporary ruinophilia relates to the prospective dimension of nostalgia, the type of nostalgia that is reflective rather than restorative and dreams of the potential futures rather than imaginary pasts" (Boym 2011). 


\section{REFERENCES}

Berger, John 2008. Sposoby Widzenia. [Ways of Seeing.] Warszawa: Fundacja Aletheia. Borne w dokumentach 1995 = Borne w dokumentach. [Borne in Documents.] Moreny: Gazeta Krainy Jezior i Lasów, No. 16, pp. 7-11.

Boym, Svetlana 2011. Ruinophilia: Appreciation of Ruins. Atlas of Transformation. Available at http://monumenttotransformation.org/atlas-of-transformation/html/r/ ruinophilia/ruinophilia-appreciation-of-ruins-svetlana-boym.html, last accessed on August 29, 2017.

Chabior, Barbara 1992. Poligony złomu pełne. [Training Grounds Full of Scrap Metal.] Gazeta Wyborcza - Legnica, No. 225, p. 2.

Czarnecka, Dominika 2015. Making Sense of the Past: (Re)constructing the Local Memorial Landscape in a Post-Soviet Base in Poland. Journal of Ethnology and Folkloristics, Vol. 9, No. 2, pp. 21-40. Available at http://www.jef.ee/index.php/ journal/article/view/204, last accessed on August 29, 2017.

Czulicki, Maciej 2014. Wybrane aspekty pobytu Pótnocnej Grupy Wojsk Armii Radzieckiej $w$ Polsce $w$ latach 1945-1993 oraz wykorzystanie infrastruktury po jednostkach Armii Radzieckiej po 1993 r. [Selected Aspects of the Northern Group of Forces of the Soviet Army's Stay in Poland in the Years 1945-1993 and the Exploitation of Infrastructure Left by the Soviet Military Units After 1993.] Warszawa: Biuro Bezpieczeństwa Narodowego. Available at https://www.bbn.gov.pl/ftp/dok/19451993.pdf, last accessed on August 29, 2017.

Demski, Dagnosław \& Czarnecka, Dominika 2015. Mapping Meanings in the Post-Soviet Landscape of Borne Sulinowo. Latvijas Vēstures Institūta Žurnāls, No. 2 (95), pp. 96-120. Available at http://www.lvi.lv/lv/LVIZ_2015_files/2numurs/D_ Demski_D_Czarnecka_Mapping_LVIZ_2015_2.pdf, last accessed on August 29, 2017.

Douglas, Mary 2001 [1966]. Purity and Danger. An Analysis of the Concepts of Pollution and Taboo. London \& New York: Routledge.

Ekologia 1994 = Ekologia. [Ecology.] Moreny: Gazeta Krainy Jezior i Lasów, No. 7, p. 9. Foucault, Michel 1984. Of Other Spaces, Heterotopias. Architecture, Mouvement, Continuité, Vol. 5, pp. 46-49. Available at https://foucault.info/doc/documents/ heterotopia/foucault-heterotopia-en-html, last accessed on August 29, 2017.

Foucault, Michel 1995 [1977]. Discipline and Punish: The Birth of the Prison. New York: Vintage Books.

Giddens, Anthony 2010. Nowoczesność i tożsamość: 'Ja'i społeczeństwo w epoce późnej nowoczesności. [Modernity and Self-Identity: Self and Society in the Late Modern Age.] Warszawa: PWN.

Golon, Mirosław 1999. Północna Grupa Wojsk Armii Radzieckiej w Polsce w latach 1945-1956: Okupant w roli sojusznika. [The Northern Group of Forces of the Soviet Army in Poland in the Years 1945-1956: The Occupant as the Ally.] Czasy Nowożytne, Vol. 6, pp. 37-115.

Gródek bez żołnierzy 1993 = Gródek bez żołnierzy, ale strzeżony. [Gródek without Soldiers but Guarded.] Moreny: Gazeta Krainy Jezior i Lasów, No. 6, p. 3.

Gródek do wzięcia 1993 = Gródek do wzięcia. [Gródek to Take.] Moreny: Gazeta Krainy Jezior i Lasów, No. 4, p. 4. 
Kamieński, Zbigniew \& Czajka, Joanna \& Bałdyga, Jerzy \& Kłuciński, Jacek (eds.) 1994. Identyfikacja i wycena szkód ekologicznych spowodowanych przez stacjonujące $w$ Polsce wojska Federacji Rosyjskiej: raport końcowy. [Identification and Valuation of Ecological Damages Caused by the Russian Federation Forces in Poland: The Final Report.] Warszawa: ELWOJ-TRIO.

Karkoszka, Janusz 1993. Są, czy nie ma? [Are They or Not?] Moreny: Gazeta Krainy Jezior i Lasów, No. 4, p. 5.

Karkoszka, Janusz 1994. Kto nie chce Bornego Sulinowa? [Who Does Not Want Borne Sulinowo?] Moreny: Gazeta Krainy Jezior i Lasów, No. 6, p. 8.

Koszty przyjaźni 1993 = Koszty przyjaźni. [Cost of Friendship.] Gazeta Wyborcza, No. 191, p. 2.

Krogulski, Mariusz L. 2001. Okupacja w imię sojuszu: Armia Radziecka w Polsce 19561993. [Occupation in the Name of Alliance: The Soviet Army in Poland 1956-1993.] Warszawa: Wydawnictwo von Borowiecky.

Ktokolwiek wie 1994 = Ktokolwiek wie... [Whoever Knows...] Moreny: Gazeta Krainy Jezior i Lasów, No. 7, p. 4.

Lund, Katrín A. \& Benediktsson, Karl 2010. Introduction: Starting a Conversation with Landscape. In: Karl Benediktsson \& Katrín A. Lund (eds.) Conversations with Landscape. Farnham: Ashgate, pp. 1-12. Available at https://www.researchgate. net/publication/293313288_Conversations_with_landscape, last accessed on August 30, 2017.

Łazarewicz, Cezary 1993. Szli na północ osadnicy. [Settlers Walked Northwards.] Gazeta Wyborcza, June 5, No. 130, p. 4. Available at http://www.archiwum.wyborcza. pl/archiwum/rok+wydania/1993?ktory=1456, last accessed on August 30, 2017.

List otwarty 1994 = List otwarty Grupy Inicjatywnej Towarzystwa Rozwoju Bornego Sulinowa oraz mieszkańców miasta. [Open Letter by the Initiative Group of the Society of Development of Borne Sulinowo and by the Inhabitants of the Town.] Moreny: Gazeta Krainy Jezior i Lasów, No. 6, p. 8.

Małachowski, Krzysztof \& Szymańska, Daniela 1994. U progu rozwoju. [On the Threshold of Development.] Moreny: Gazeta Krainy Jezior i Lasów, No. 2, p. 5.

Małolepszy, Robert 1995. Raport o stanie: Pytania o Borne. [Report on the Condition: Questions about Borne.] Moreny: Gazeta Krainy Jezior i Lasów, No. 20, pp. 8-9.

Milton, Kay 1996. Environmentalism and Cultural Theory: Exploring the Role of Anthropology in Environmental Discourse. London \& New York: Routledge.

Min nie ma 1993 = Min nie ma! Ale... [There Are No Mines! But...] Moreny: Gazeta Krainy Jezior i Lasów, No. 3, p. 5.

Mirzoeff, Nicholas 2016. Jak zobaczyć świat. [How to See the World.] Kraków \& Warszawa: Karakter.

Murphy, Dean E. 1994. Nowe życie w polskim Dodge City. [New Life in the Polish Dodge City.] Moreny: Gazeta Krainy Jezior i Lasów, No. 1, pp. 4-5.

Pisali o nas 1995 = Pisali o nas. [They Were Writing about Us.] Moreny: Gazeta Krainy Jezior i Lasów, No. 10, p. 8.

Poczobutt, Alicja 2003. Zanim otwarto miasto - część III. [Before the Opening of the City - Part III.] Magazyn Miasta i Gminy, pp. 28-29.

Pomysł na Borne 1994 = Pomysł na Borne - przywracanie życia. [Idea of Borne Restoration of Life.] Moreny: Gazeta Krainy Jezior i Lasów, No. 7, p. 8. 
Potwór 1994 = Potwór z Loch Ness w Jez. Pile. [Loch Ness Monster in Pile Lake.] Moreny: Gazeta Krainy Jezior i Lasów, Nos. 4-5, p. 1.

Potyrała, Bolesław 1995. Północna Grupa Wojsk Armii Radzieckiej w Polsce i w województwie legnickim. [The Northern Group of Forces of the Soviet Army in Poland and in Legnica Voivodeship.] Szkice Legnickie, Vol. 17, pp. 117-127.

Rozgoryczenie 1994 = Rozgoryczenie i wstyd. [Bitterness and Shame.] Moreny: Gazeta Krainy Jezior i Lasów, No. 6, p. 8.

Rząd 1994 = Rząd. [Government.] Moreny: Gazeta Krainy Jezior i Lasów, Nos. 4-5, p. 5. Są, czy 1993 = Są, czy nie ma? [Are They or Not?] Moreny: Gazeta Krainy Jezior i Lasów, No. 4, p. 1.

Szpindor, Robert 1992. Garnizon do wynajęcia. [The Garrison to Rent.] Gazeta WyborczaKoszalin, No. 235, p. 5.

Sztyler, Andrzej 1994. Kresowiacy w Gródku. [East Poles in Gródek.] Moreny: Gazeta Krainy Jezior i Lasów, No. 6, p. 15.

Sztyler, Andrzej 1995. Gródkowe dylematy. [Dilemmas in Gródek.] Moreny: Gazeta Krainy Jezior i Lasów, No. 12, pp. 12-13.

Szulc, Tomasz \& Nicpoń, Krzysztof 2007. Magazyny broni jądrowej na terytorium Polski. [Storehouses for Atomic Weapons in Poland.] Poligon, No. 3, pp. 62-77.

Wybuchowe Borne 1995 = Wybuchowe Borne! [Explosive Borne!] Moreny: Gazeta Krainy Jezior i Lasów, No. 15, p. 1. 